\title{
Health Education for the Migrant Farm Working Community in El Paso, Texas through the Integration of Faculty Research and Student Learning
}

\author{
Sharon E. Thompson and Jane E. Poss \\ The University of Texas at El Paso
}

\begin{abstract}
Resumen
A needs assessment among the migrant farm workers on the US/Mexico border of El Paso, Texas was conducted as part of the Migrant Border Health Initiative. Based on the survey results, recommendations for potential health education programs were provided to the undergraduate community health students at The University of Texas at El Paso. These students directly applied the principles they learned in their program planning and evaluation course to the development and implementation of health educational interventions for this underserved migrant community. It was necessary for the students to develop creative, innovative and nontraditional strategies to address the learning needs of the farm workers. The ultimate goal of these educational programs was to assist the farm workers in making informed decisions to improve their health. Based on the success of these initial presentations, others are being planned for the spring.

Una evaluación de las necesidades de los trabajadores agrícolas emigrantes en la frontera Estados Unidos/México de El Paso, Texas fue conducida como parte de la Iniciativa de Salud para los Emigrantes en la Frontera. Basado en los resultados del estudio, se presentaron recomendaciones de programas viables de educación sobre la salud a los estudiantes de salud comunitaria de la Universidad de Texas en el Paso. Estos estudiantes aplicaron directamente los principios que ellos aprendieron en su curso de planeación y evaluación de programas para el desarrollo e implementación de intervención educacional de salud para esta comunidad de emigrantes que no tiene acceso a cuidado de salud. Fue necesario para los estudiantes desarrollar estrategias creativas, innovadoras y notradicionales para satisfacer las necesidades de aprendizaje de los trabajadores agrícolas. El objetivo principal de estos programas educativos fue asistir a los trabajadores agrícolas a tomar decisiones para mejorar su salud. Basados en el éxito de estas primeras presentaciones, se están planeando otras para la primavera.
\end{abstract}

(C) 2003 Californian Journal of Health Promotion. All rights reserved. Keywords: Health education, Farm worker, Border, and Program planning

\section{Overview}

Program planning, implementation, and evaluation are some of the most central responsibilities of the health educator. Most undergraduate health education curricula require a course or two in this process area culminating with an internship experience. This content is often presented from a theoretical perspective because planning, implementing and evaluating an actual health education program is difficult to accomplish in the course of a single semester. The undergraduate community health education students at The University of Texas at El Paso
(UTEP) were afforded the opportunity to directly apply the principles they learned in their program planning and evaluation course to the development and implementation of health educational interventions for the vastly underserved migrant farm working community on the border region.

Dr. Jane Poss, Professor of Nursing at UTEP and Director of the Family Nurse Practitioner Program, is a co-principal investigator on the Migrant Border Health Initiative (MBHI) and has worked extensively in migrant populations. 
The MBHI is a joint effort between Texas Tech University Health Sciences Center El Paso and UTEP that evolved due to the severe lack of detailed and reliable data about migrant farm workers on the Texas/New Mexico border. The MBHI goals are: 1.) to develop a regional database for area migrant workers and their families, 2.) to establish foundation for future research into migrant farm worker health issues, 3.) to initiate health education interventions and directives, and lastly 4.) to evaluate obstacles preventing migrant farm workers from accessing health care in the US (Poss, 2002).

A needs assessment among the migrant farm workers on the US/Mexico border of El Paso, Texas was conducted as part of the MBHI. The MBHI survey was administered to 150 migrant/seasonal farm workers. The vast majority of the interviews were conducted at the Centro de Trabajadores Agricolas (Migrant Home) in downtown El Paso. Other interviews were conducted in La Union and Anthony, New Mexico, Clint, Fabens, Tornillo, San Elizario, and Socorro, Texas. Based on the survey results, Dr. Poss provided recommendations for potential health education programs. Topics for these programs included but were not limited to diabetes, hypertension, nutrition, obesity and tuberculosis. Dr. Poss invited the undergraduate community health education students to participate in the development and implementation of health education programs to address the needs of this migrant farm working population. These results and recommendations were presented to the students enrolled in a program planning and evaluation course.

\section{Program Development}

The students were charged with selecting a recommended topic and developing an educational intervention to be administered to the migrant farm workers residing at the Migrant Home. The students utilized a systematic approach in the development of these programs following the phases of the PRECEDE/ PROCEED model (Green \& Kreuter, 1998). The semester was spent exploring the principles of program planning, implementation, and evaluation then immediately applying these principles to the development of the educational interventions for the migrant farm workers. A suggested outline and format for the program report were provided. Students worked in groups of two or three. All groups were bilingual. The educational interventions were presented to the class at the end of the semester, and a written report was submitted to the instructor.

The following semester, all groups were invited to present their educational interventions to the migrant farm workers at the Migrant Home. Four of the six groups enthusiastically agreed to participate. Students from the other two groups had graduated and were unable to take part. The four groups presented on the topics of proper hand washing, stress management, tuberculosis, and skin cancer.

Faculty in the College of Health Sciences had previously secured a grant from The Paso del Norte Health Foundation, a private foundation, to fund student research and student projects under the Health Oriented Topics (HOT) Initiative. The mission of the Paso del Norte Health Foundation is to "affect long term improvements in the health status of the population in the Greater El Paso Region through education and prevention" (Paso del Norte Health Foundation, 2003). The HOT Projects initiative was developed to provide funding to institutes of higher learning in order to support student-lead projects in areas related to the mission of the foundations (PDNHF, 2003).

The students received exposure to the proposal writing process, which will be of great benefit in their future careers. Grantsmanship skills are vital to program planners because of the limited amount of money available for health promotion programs (McKenzie \& Smeltzer, 2001). Three of the four participating groups applied and all were awarded these funds ranging from approximately $\$ 600.00$ to $\$ 900.00$. The students were able to purchase educational aids, incentives, and other accoutrements needed to implement their educational interventions.

UTEP Students are afforded the use of the stateof-the-art technology when presenting projects 
and research during their academic careers. However, this level of technology is rarely available in most of the economicallychallenged border communities in which the students may work upon graduation. It is imperative that these future health educators develop the skills necessary to provide quality health education with limited resources. This was one of the greatest challenges of this project. It was necessary for the students to develop creative, innovative and non-traditional strategies to address the learning needs of the migrant farm workers whose mean educational level was approximately fifth grade (Poss, 2002).

\section{Implementation}

The educational programs were conducted four consecutive evenings at the Migrant Home after the farm workers had returned from the fields. All presentations were given in Spanish. Due to the low-literacy level of the population, very little to no written literature was provided. Verbal communication and visual aids were utilized to convey information and concepts. Approximately 50-60 migrant farm workers attended the presentations each night. The presentations lasted from one to one and half hours. A brief description of each educational intervention follows.

\section{Hand Washing}

This group developed an educational program that addressed the very basic principles of disease transmission and proper hand washing techniques. This group selected the topic because hand washing is a simple and effective method of reducing both the spread of some communicable diseases, as well as exposure to pesticides. The students began by presenting basic information about the chain of infection. The students performed a skit to elucidate this concept.

Proper hand washing techniques were then demonstrated. The Happy Birthday song is often used to gauge the appropriate length of time to wash one's hands. The students substituted this song with Las Mañanitas, a widely known and more culturally appropriate selection. The audience members were asked to demonstrate the proper hand washing with soap and water in basins that had been purchased. The students observed the farm workers and provided suggestions and modifications where appropriate. After the successful completion of proper hand washing, the migrant farm workers were served empanadas.

\section{Stress Management}

The second educational program focused on the effects of stress on the body and techniques in the management of stress. Breathing exercises and visualization were taught. Soothing mariachi music was played in the background. The students distributed scenic photographs for the farmers to practice their visualization individually. Refreshments were served at the end of the session and door prizes were distributed.

\section{Tuberculosis}

This group presented basic information about tuberculosis (TB) and the mode of transmission (see Figure 1). To elucidate the concept of droplet dispersal following a coughing spell, a spray bottle was utilized. Information and contact numbers for community resources for TB screening were also provided. In addition, the students coordinated with a local health clinic to provide TB screenings to the farm workers who desired such. A nurse from the clinic returned to the Migrant Home to read the results of the TB tests two days later. Refreshments were provided at the end of the educational session.

\section{Skin Cancer Prevention}

The final group gave a presentation entitled "Sun Sensibility." The students presented the basic facts, as well as the ABCDs of skin cancer (see Figure 2). In addition, the students used the raisin-grape activity in which the raisin represented skin that has been over exposed to the sun and the grape represented healthy skin that has been protected. The students discussed primary prevention through the use of hats, sunscreen, long sleeve shirt, and sunglasses. At the end of the educational intervention, the student provided the participants with hats, sunglasses, sunscreen, and refreshments. 


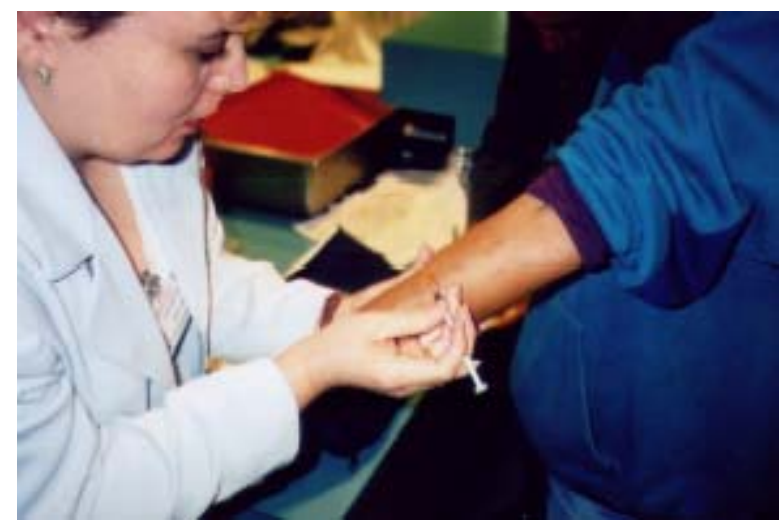

Figure 1

TB Tuberculin Test

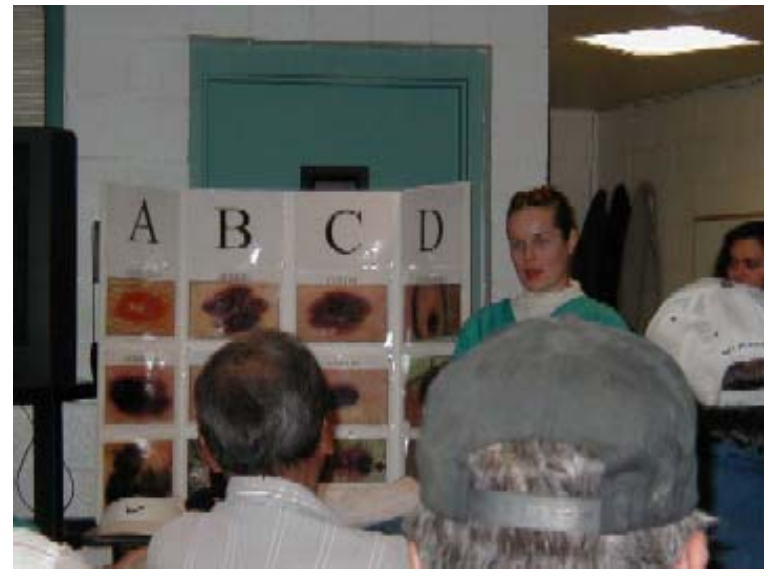

Figure 2

Sun Sensibility Presentation

\section{Conclusion}

The students evolved throughout the course of the project and gained a sense of confidence in their ability to both plan and implement educational programs. "Taking part in the migrant farm worker project was very rewarding because it allowed me to use the concepts I learned in my programming and evaluation class in order to design an educational program for the workers to improve their quality of life" (Leyva,
2003). The students gained invaluable skills that they will utilize in their future careers as health educators.

The MBHI survey revealed that only approximately twenty percent of the migrant farm workers questioned had ever received health-related education while working in the United States ("Migrant Center", 2002). It was tremendously rewarding for both the faculty and 
the students to provide important health education to this vastly underserved community. This education is designed to assist the individual to make informed decisions to improve their health and their quality of life.
This is but the first step in a mutually beneficial collaboration. Based on the success of these initial presentations, others are being planned for the spring.

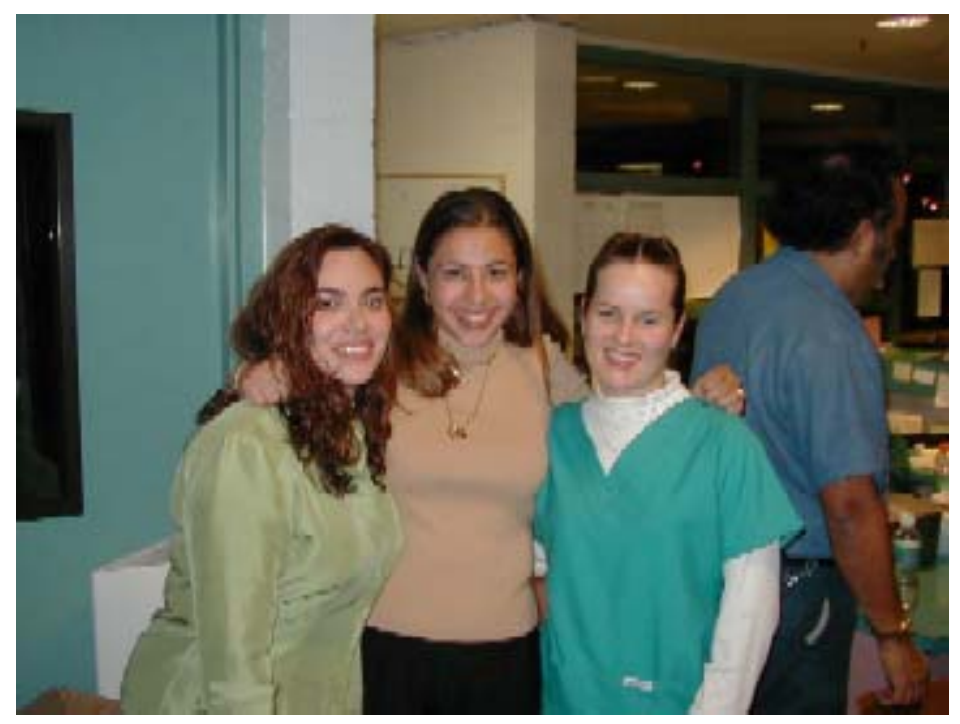

Figure 3

Student Participants

\section{References}

Green, L. W., \& Kreuter, M. W. (1999). Health promotion planning: An educational and ecological approach (3rd ed.). Mountain View, CA: Mayfield Publishing Company.

Leyva, M. (2003). Participating student. Personal Interview.

McKenzie, J. F., \& Smeltzer, J. L. (1997). Planning, implementing, and evaluating health promotion programs. Boston: Allyn and Bacon.

Staff. (December 2002). Migrant center into classroom for health students. Horizons, p. 2.

Paso del Norte Health Foundation. (2003). HOT projects initiative. Retrieved February 20, 2003, from http://www.pdnhf.org

Poss, J. E. (July 2002). The migrant border health initiative. Lecture. El Paso, TX: University of Texas at El Paso.

\section{Acknowledgements}

This project was supported in part by funds from the Office of Rural Health Policy (ORHP) Special Projects, Health Resources and Services Administration (HRSA), Department of Health and Human Services (DHHS) under grant number \#1-DIA-RH-00007-01 entitled "Migrant Border Health Initiative". The information or content and conclusions are those of the authors and should not be construed as the official position or policy of, nor should any endorsements be inferred by the ORHP, BHPr, DHHS or the U.S. Government. 
In addition, the project described was supported, in part, by a grant from the Paso del Norte Health Foundation through the Health Oriented Topics (HOT) Initiative. Its contents are solely the responsibility of the authors and do not necessarily represent the official views of the Paso del Norte Health Foundation or the HOT Projects Initiative.

\section{$\underline{\text { Author Information }}$}

Sharon E. Thompson, MPH, Ph.D., CHES

Assistant Professor

Health Science Program

The University of Texas at E1 Paso

1101 North Campbell Street

El Paso, Texas 79902

Ph. (915) 747-7221

Fax. (915) 747-7207

E-mail: sthompson@utep.edu

Jane E. Poss, DNSc, APRN, BC

Professor and Director

Family Nurse Practitioner Program

The University of Texas at El Paso 